\title{
Molybdate sulfuric acid (MSA): a novel and efficient solid acid reagent for the oxidation of thiols to symmetrical disulfides
}

\author{
Morteza Montazerozohori,* Bahador Karami, and Mahbobeh Azizi \\ Department of Chemistry, Yasouj University, Yasouj 75918-74831, P. O. Box-353 Iran \\ E-mail:1mmzohori@mail.yu.ac.ir,mmzohory@yahoo.com
}

\begin{abstract}
Wet molybdate sulfuric acid (MSA), as a new solid acid can be used in combination with sodium nitrite to transform a variety of thiols to the corresponding symmetric disulfides under mild and heterogeneous conditions. The process has several advantages: the reagents are inexpensive and non-hazardous, the reaction is clean, fast, high-yielding and MSA can be readily removed by filtration and re-used after treatment with $\mathrm{HCl}$ without loss of activity. Further, only thiol oxidation to disulfide was observed.
\end{abstract}

Keywords: Disulfides, oxidation, thiols, molybdate sulfuric acid

\section{Introduction}

Currently, the search about application of heterogeneous chemical systems is an active field both in industry and academia especially in view of simplified handling procedures, reduction of corrosion, avoidance of undesired by-products, clean and easily work-up procedures. With regard to the wide application of acids as reagents or catalysts in organic chemistry, the introduction of an inorganic solid acid can be useful in this direction. Several solid acids such as silica sulfuric acid ${ }^{1}$ and Nafion- $H^{2}$ have been used for a wide variety of chemical transformations, e.g., preparation of disulfides from thiols ${ }^{1}$, oxidation of 1,4-dihydropyridines, ${ }^{3}$ $\mathrm{N}$-nitrosation of secondary amines, ${ }^{4}$ acetal deprotection, ${ }^{5}$ oxidation of alcohols, ${ }^{6}$ alkylation and acylation, ${ }^{7}$ isomerization, ${ }^{8}$ transalkylation, ${ }^{9}$ nitration, ${ }^{10}$ ether and ester synthesis, ${ }^{11}$ acetal formation, ${ }^{12}$ and rearrangements. ${ }^{13}$ Disulfides have an important role in chemical synthesis. In biological systems they control the cellular redox potential and prevent oxidative damage. ${ }^{14-15}$ Several methods based on oxidative S-S coupling have been reported for the synthesis of disulfides from thiols and protected thiols including coupling with redox dyes ${ }^{16}$, diazocompounds ${ }^{17}$ sulfoxides, ${ }^{18}$ halogens, ${ }^{19} \mathrm{H}_{2} \mathrm{O}_{2},{ }^{20} \mathrm{KMnO}_{4} / \mathrm{CuSO}_{4},{ }^{21} \mathrm{DMSO} / \mathrm{I}_{2},{ }^{22}$ sodium perborate, ${ }^{23}$ Bismuth(III) Nitrate Pentahydrate, ${ }^{24}$ 1,3-Dibromo-5,5-Dimethylhydantoin ${ }^{25}$ and electrochemical methods. ${ }^{26}$ In continuation of our recent studies ${ }^{27}$ on the application of inorganic 
solid acids, we herein present molybdate sulfuric acid (MSA) as a new solid acid. MSA (1) was prepared according to a previously published protocol ${ }^{27}$ as shown in Scheme 1.

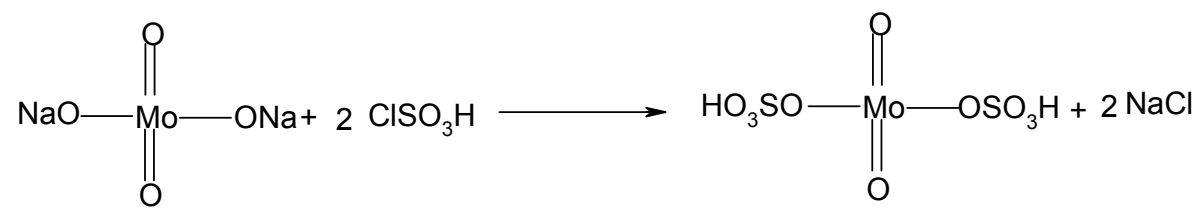

\section{Scheme 1}

This inorganic solid acid in combination with $\mathrm{NaNO}_{2}$ was observed to be an efficient and heterogeneous system for the oxidation of thiols.

\section{Results and Discussion}

First, we were interested to examine MSA (1) as a $\mathrm{H}^{+}$source in combination with various oxidants in organic solvents. For this reason, we chose wet $10 \%(w / w) \mathrm{MSA} / \mathrm{NaNO}_{2}$ for the oxidative coupling of a series of aliphatic and aromatic thiols (1-13a) which were transformed to the corresponding disulfides (1-13b) in $\mathrm{CH}_{2} \mathrm{Cl}_{2}$ or methanol. All reactions were run under mild and heterogeneous conditions at room temperature and gave the expected disulfides in good-toexcellent yields (Table 1). Based on other literature reports, ${ }^{1 \text { a, } 28-29}$ we propose that the reactions proceed via formation of $\mathrm{NO}^{+}$upon reaction of wet $\mathrm{MSA}(\mathbf{1})$ with $\mathrm{NaNO}_{2}$ producing thionitrite 2 which converts to the related disulfides due to its instability under the reaction conditions according to Scheme 2 .

The above proposed mechanism shows that the MSA (1) after a process remains as its sodium salt and therefore can be reusable acidic reagent. Thus, the recovered MSA from the oxidation reaction of, e.g., 5a was used again in another reaction with $\mathrm{NaNO}_{2}$, which afforded the related disulfide $\mathbf{5 b}$ in $92 \%$ yield (compared to $98 \%$ in the first run; see Table 1).

For increasing the rate of the oxidation reaction one could use an excess of $\mathrm{NaNO}_{2}$, but because of the probable nitrosation of the formed disulfides, this was avoided (Table 1). Finally, it is noteworthy to point to the role of $\mathrm{H}_{2} \mathrm{O}$ in the $\mathrm{MSA} / \mathrm{NaNO}_{2}$ system. We decided to run a series of parallel reactions under anhydrous conditions or hydrous conditions (wet MSA(1)). The results clearly indicate that $\mathrm{H}_{2} \mathrm{O}$ is essential for the generation of $\mathrm{HNO}_{2}$ (see Scheme 2), since no oxidation was observed under strictly anhydrous conditions. 
Table 1. Oxidation of thiols to the corresponding disulfides with wet $\mathrm{MSA}(\mathbf{1}) / \mathrm{NaNO}_{2}$ in dichloromethane or methanol at room temperature

\begin{tabular}{|c|c|c|c|c|c|}
\hline Entry & Thiol (a) & Disulfide (b) ${ }^{\mathrm{a}}$ & Time (min.) & Yield ${ }^{b}(\%)$ & $\begin{array}{l}\text { M.p. }\left({ }^{\circ} \mathrm{C}\right) \\
\text { Found (Lit.) }\end{array}$ \\
\hline 1 & & & 10 & 94 & $144-146(142-145)^{24}$ \\
\hline 2 & & & 10 & 96 & $43-44(44-45)^{24}$ \\
\hline 3 & & & 20 & 95 & $72-73(70-71)^{24}$ \\
\hline 4 & & & 7 & 94 & $90-92(91-93)^{24}$ \\
\hline 5 & & & 15 & 90 & $177-179(177-180)^{*}$ \\
\hline 6 & & & 10 & 90 & $55-56(55-67)^{24}$ \\
\hline 7 & & & 10 & 90 & $133-135(134-136)^{32}$ \\
\hline 8 & & & 15 & 95 & $59-60(58-59)^{24}$ \\
\hline 9 & $\mathrm{CH}_{3}\left(\mathrm{CH}_{2}\right)_{2} \mathrm{CH}_{2} \mathrm{SH}$ & $\left(\mathrm{CH}_{3}\left(\mathrm{CH}_{2}\right)_{2} \mathrm{CH}_{2} \mathrm{~S}\right)_{2}$ & 18 & 85 & $\mathrm{Oil}^{25}$ \\
\hline 10 & $\mathrm{CH}_{3}\left(\mathrm{CH}_{2}\right)_{6} \mathrm{CH}_{2} \mathrm{SH}$ & $\left(\mathrm{CH}_{3}\left(\mathrm{CH}_{2}\right)_{6} \mathrm{CH}_{2} \mathrm{~S}\right)_{2}$ & 20 & 84 & $\mathrm{Oil}^{25}$ \\
\hline 11 & n-BuSH & $(\mathrm{n}-\mathrm{BuS})_{2}$ & 20 & 90 & Oil $^{24}$ \\
\hline 12 & $\mathrm{c}-\mathrm{C}_{6} \mathrm{H}_{11} \mathrm{SH}$ & $\left(\mathrm{c}-\mathrm{C}_{6} \mathrm{H}_{11} \mathrm{~S}\right)_{2}$ & 20 & 85 & $\mathrm{Oil}^{24}$ \\
\hline 13 & & & 16 & 90 & $68-70(70-71)^{24}$ \\
\hline
\end{tabular}

${ }^{a}$ Identified by comparison with those reported in the literature. ${ }^{b}$ Refers to isolated yields. *Chemical and Reagents 2005-2007 MERCK. 


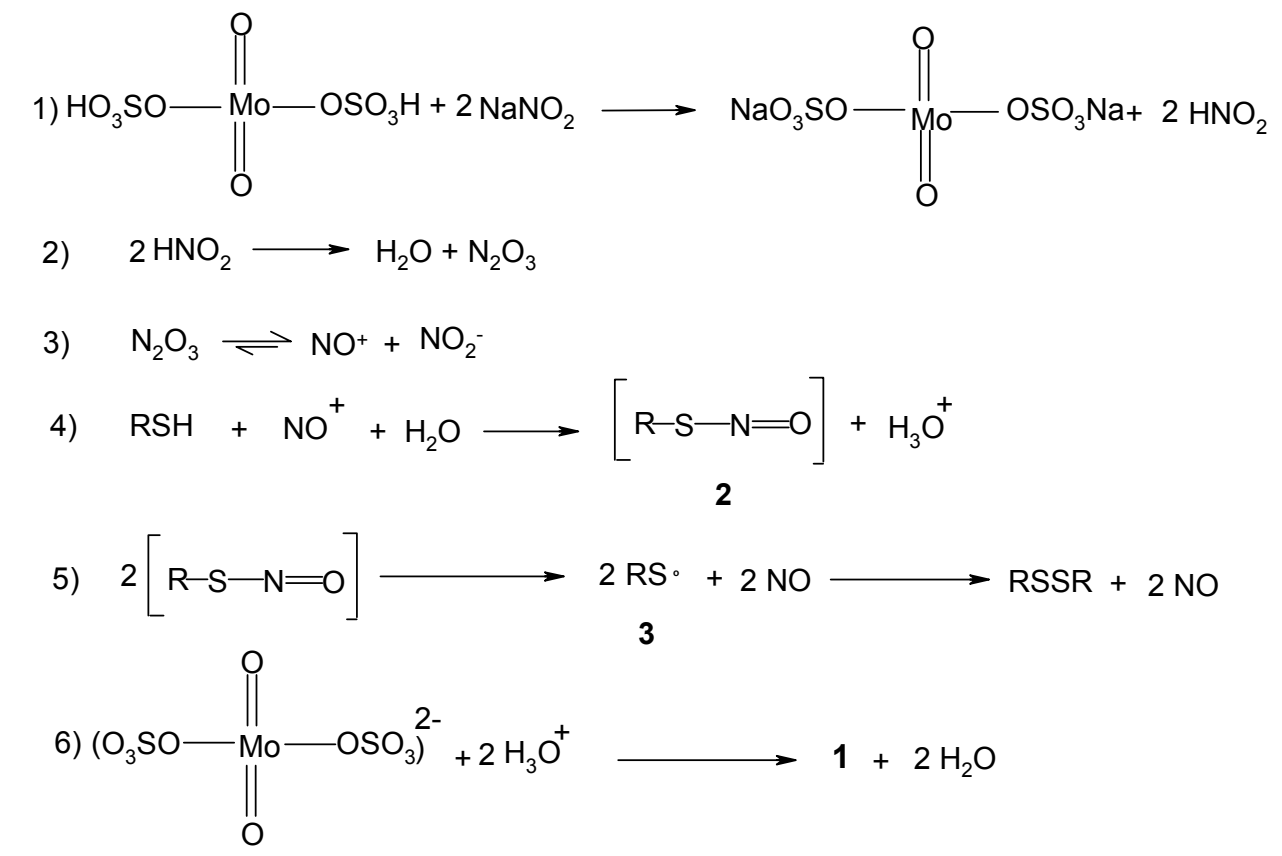

\section{Scheme 2}

\section{Conclusions}

In this paper we have reported the use of molybdate sulfuric acid MSA, (1) as a novel heterogeneous solid acid in a convenient, efficient and practical method for the effective oxidation of thiols. The availability of the reagents, facile synthesis of MSA(1), the easy and clean work-up of products and the high yields make this method a useful alternative to literature methodologies.

\section{Experimental Section}

Thiols and the other chemicals were purchased from Merck, Fluka and Aldrich. The reactions were monitored by TLC (silica-gel $60 \mathrm{~F}_{254}$, n-hexane: ethyl acetate). The products were isolated and identified by comparison of their physical and spectral data with those reported in the literature. ${ }^{24,} 25,28-32$ IR spectra were recorded on a FT-IR JASCO-680 spectrometer and the ${ }^{1}$ HNMR spectra were obtained on a Brucker-instrument DPX-300 MHz Avance 2 model.

Preparation of molybdate sulfuric acid (MSA). To chlorosulfonic acid (23.304 g, $0.2 \mathrm{~mol})$ in a $250 \mathrm{~mL}$ round-bottom flask immersed in an ice bath, anhydrous sodium molybdate $(20.58 \mathrm{~g}, 0.1$ mol) was added gradually. After completion of the addition, the mixture was shaken for $1 \mathrm{~h}$, which gave rise to crude MSA as a bluish-white solid, which was filtered off and washed with cold $\mathrm{H}_{2} \mathrm{O}$. Yield: $28 \mathrm{~g}\left(87.5 \%\right.$; m.p. $\left({ }^{\circ} \mathrm{C}\right)=356$ (dec.)). The Compound is dissolved a little in 
water and not in the organic solvents. Characteristic IR bands $\left(\mathrm{KBr}, \mathrm{cm}^{-1}\right) ; 3600-2200(\mathrm{OH}, \mathrm{bs})$, 1230-1150 ( $\mathrm{S}=\mathrm{O}, \mathrm{bs}), 1050(\mathrm{~S}-\mathrm{O}, \mathrm{m}), 1010(\mathrm{~S}-\mathrm{O}, \mathrm{m}), 880-840(\mathrm{Mo}=\mathrm{O}, \mathrm{m})$ and 450(Mo-O, m).

Oxidation of thiols: a general procedure. To a solution of $2 \mathrm{mmol}$ of thiol in $8 \mathrm{~mL}$ dichloromethane or methanol, $1 \mathrm{mmol}$ of wet MSA (1) $(10 \% \mathrm{w} / \mathrm{w})$ and $2 \mathrm{mmol}$ of $\mathrm{NaNO}_{2} \mathrm{were}$ added. The reaction mixture was stirred at room temperature and a light-green heterogeneous solution was obtained rapidly and then disappeared. The reaction was monitored by TLC (nhexane: ethyl acetate, 15: 5). The reaction mixture was filtered and washed with $2 \times 4 \mathrm{~mL}$ dichloromethane or methanol (for some products). Dichloromethane or methanol was removed by water bath. The yields were summarized in Table 1 .

\section{Acknowledgements}

The authors gratefully acknowledged partial support of this work by the Yasouj University, Yasouj, Iran.

\section{References}

1. (a) Zolfigol, M. A. Tetrahedron 2001, 57, 9509. (b) Shaabani, A.; Sol eimani, K.; Bazgir, A. Synth. Commun. 2004, 34, 3303.

2. Olah, G. A.; Molhotra, R. S.; Narang, C. J. Org. Chem. 1987, 43, 4628.

3. Zolfigol, M. A.; Shirini, F.; Ghorbani Choghamarani, A.; Mohammadpoor-Baltork, I. Green Chem. 2002, 4, 562.

4. Zolfigol, M. A.; Bamoniri, A. Synlett 2002, 1621.

5. (a) Mirjalili,B. F.; Zolfigol, M. A.; Bamoniri, A. J. Kor. Chem. Soc. 2001, 45, 546. (b) Mirjalili, B. F.; Zolfigol, M. A.; Bamoniri, A. Molecules 2002, 7, 751.

6. (a) Mirjalili, B. F.; Zolfigol, M. A.; Bamoniri A.; Zarei, A. Bull. Kor. Chem. Soc. 2003, 24, 400. (b) Mirjalili, B. F.; Zolfigol, M. A.; Bamoniri, A.; Zaghaghi, Z. J. Chem. Res. (S) 2003, 273. (c) Mirjalili, B. F.; Zolfigol, M. A.; Bamoniri, A.; Zaghaghi, Z.; Hazar, A. Acta Chem. Slov. 2003, 50, 563. (d) Shirini, F.; Zolfigol, M. A.; Mohammadi, K. Bull. Kor. Chem. Soc. 2004, 25, 325.

7. Chitnis, S. R.; Sharma, M. M. J. Catal. 1996,160, 84.

8. 8(a) Salomatina, O. V.; Yarovaya, O. I.; Korchagina, D. V.; Polovinka, M. P.; Barkhash, V. A. Mendelee. Commun. 2005, 59. (b) Seen, A. J. J. Chem. Educ. 2004, 81, 383.

9. Takeuchi, G.; Shimoura, Y. Catal. Surv. Jpn. 1998, 2, 77.

10. Choudary, B. M.; Sateesh, M.; Lakshmi Kantam, M.; Koteswara Rao, K.; Ram Prasad, K. V.; Raghavan, K. V.; Sarma, J. A. R. P. Chem. Commun. 2000, 25.

11. Yadav, G. D.; Rahuman, M. S. M. Org. Pro. Res. Dev. 2002, 6, 706.

12. Ledneczki, I.; Molnar, A. Synth. Commun. 2004, 34, 3683. 
13. (a) Harmer, M. A.; Sun, Q. Appl. Catal. A: General 2001, 45, 221 and references therein. (b) Elings, J. A.; Lempers, H. E. B.; Sheldon, R. A. Eur.J. Org. Chem. 2000, 1905.

14. Pe'er, I. C.; Felder, E.; Man, O.; Silman, I.; Sussman, J. L. Proteins 2004, 54, 20.

15. Bardwell, J. C. Mol. Microbiol. 1994, 14, 199.

16. Kharasch, N.; Arora, A. S. Phosphorus Sulfur Silicon 1976, 2, 1.

17. Kosower, E. M.; Kosower, N. S. Nature 1969, 224, 117.

18. (a) Wallace, T. T. J. Am. Chem. Soc. 1964, 86, 2018. (b) Wallace, T. T.; Wein, H. A. Chem. Ind.(London) 1966, 1558 .

19. Small, D. L.; Bailey, J. H.; Cavallito, G. J. J. Am. Chem. Soc. 1947, 69, 1711.

20. Evans, B. J.; Doi, J. T.; Musker, W. K. J. Org. Chem. 1990, 55, 2337.

21. Noureldin, N. A.; Caldwell, M.; Hendry, J.; Lee, D. G. Synthesis 1998, 1587.

22. (a) Aida,T.; Akasaka,T.; Furukawa, N.; Oae, S. Bull. Chem. Soc. Jpn. 1976, 49, 1441. (b) Fristad,W. E.; Peterson, J. R. Synth. Commun. 1985, 15, 1.

23. McKillop, A.; Koyuncu, D. Tetrahedron Lett. 1990, 31, 5007.

24. Khodaei, M. M.; Mohammadpoor- Baltork, I.; Nikoofar, K. Bull. Kor. Chem. Soc. 2003, 24, 885 and references therein.

25. Khazaei, A.; Zolfigol, M. A.; Rostami, A. Synthesis 2004, 2959.

26. Leite, S. L. S.; Pardini, V. L.; Viertler, H. Synth. Commun. 1990, 20, 393.

27. (a) Karami, B.; Montazertozohori, M.; Habibi, M. H. Bull. Kor. Chem. Soc. 2005, 26, 1125.

(b) Karami, B.; Montazertozohori, M.; Karimipour, Gh.; Habibi, M. H. Bull. Kor. Chem. Soc. 2005, 26, 1431. (c) Karami, B.; Montazerozohori, M.; Habibi, M. H.; Zolfigol, M. A. Heterocyclic Commun. 2005, 11, 513. (d) Karami, B.; Montazerozohori, M.; Habibi, M. H. Phosphuros, Sulfur, Silicon and Related Elements, 2006, 181, 2825. (e) Montazerozohori, M.; Karami, B. Helv. Chim. Acta 2006, 89, 2922.

28. Iranpoor, N.; Firouzabadi, H.; Zolfigol, M. A. Synth. Commun. 1998, 28, 367.

29. Firouzabadi, H.; Iranpoor, N.; Zolfigol, M. A. Synth. Commun. 1998, 28, 1179.

30. Zolfigol, M. A.; Nematollahi, D. Mallakpour, S. E. Synth. Commun. 1999, 29, 2277.

31. Zolfigol, M. A. Synth. Commun. 2000, 30, 1593.

32. Jensen,G. B.; Smith, G.; Sagatys, D. S.; Healyb, P. C.; White, J. M. Acta Cryst., 2004, E60, 2438 